\title{
УДК 519.177:657.6:658.821(045)
}

\section{Коцеруба Н. В.}

nata0319830@gmail.com,ORCIDID:0000-0001-5161-318X

ResearcherID: https://publons.com/researcher/3342956/nataliya-kotseruba

к.е.н., дои., доиент кафедри обліку та оподаткування,

Вінницький торговельно-економічний інститут

Київського національного торговельно-економічного університету, м. Вінниця

\section{КОНТРОЛЬНО-АНАЛІТИЧНІ ПРОЦЕДУРИ В СИСТЕМІ КРИЗИС-МЕНЕДЖМЕНТУ ПІДПРИЕМСТВА}

\begin{abstract}
Анотація. Загострення кризи світової економіки актуалізує необхідність мінімізації впливу кризових ризиків на результати економічної діяльності підприємств. Подї попереднього та поточного років свідчать про те, щчо найбільше потерпають від наслідків кризи мікро-, малі та середні підприємства, які на відміну від великих підприємств не мають ефективних запобіжників для своєчасного виявлення та попередження кризових загроз. Це вимагає від суб'єктів підприємницької діяльності своєчасного виявлення, пери за все, операційних ризиків, до яких належсать зменшення обсягів діяльності $i$, як наслідок, уповільнення зростання операційних доходів $і$ зменшення операційного прибутку, щуо призводить до загострення фінансових ризиків - зниження рентабельності операційної діяльності, а також рентабельності активів та капіталу підприємства і погіршення фінансового стану підприємств.

Чинники кризи як предмет антикризового управління являють собою явища, щзо є причинами порушення стабільного розвитку підприємства. Залежно від середовищза виникнення чинники кризи розподіляються на зовнішні (на зміну яких окреме підприємство впливати не може) та внутрішні (які піддаються регулюванню з боку систем антикризового управління підприємством).

Ефективне антикризове управління підприємством торгівлі трунтується на використанні інформації стосовно показників операційної і фінансової діяльності, негативна зміна яких призводить до утворення кризових ситуацій.

Із метою визначення проблемних ланок діяльності підприємства торгівлі запропоновано моделювання операційного прибутку, щзо розраховується методом прямого рахунку: збільшення доходів та зменшення витрат створюють приріст прибутку, а зниження доходів та зростання витрат зменшують прибуток на відповідну величину. Для зниження ризику та втрати платоспроможності підприємства рекомендовано використання платіжного календаря. Грошові потоки у платіжному календарі групуються за видами діяльності відповідно до напрямів надходження і витрачання коштів, щзо дає змогу своєчасно встановити потенційні кризові загрози та сформувати критерії оцінки ризику неплатоспроможності. Доцільне використання методики оцінки потениійного банкрутства за системою формалізованих і неформалізованих критеріїв, щзо доповнена показником власного оборотного капіталу, від 'ємне значення якого є ознакою критичного фінансового стану суб' єкта господарювання.

Зважаючи на обмежені ресурси кризис-менеджменту значної кількості підприємств, щзо діють на товарному ринку України, у статті запропоновано систему контрольно-аналітичних процедур, застосування яких дає змогу очінити ризики та визначити орієнтири безпечної економічної діяльності, не залучаючи фахівців консалтингових аудиторських фірм та маркетингових агентств.
\end{abstract}

Ключові слова: підприємство торгівлі, кризис-менеджмент, контрольно-аналітичні процедури, операційні та фінансові ризики, мінімізація кризових загроз.

\section{Kotseruba Nataliia}

Enata0319830@gmail.com,ORCID ID: 0000-0001-5161-318X

ResearcherID: https://publons.com/researcher/3342956/nataliya-kotseruba

Ph.D., Associate Professor,

Associate Professor at the Department of Accounting and Taxation,

Vinnytsia Trade and Economic Institute

of Kyiv National University of Trade and Economics, Vinnytsia

\section{CONTROL AND ANALYTICAL PROCEDURES IN THE CRISIS MANAGEMENT SYSTEM OF THE ENTERPRISE}

\footnotetext{
Abstract. The aggravation of the crisis of the world economy highlights the need to minimize the impact of crisis risks on the results of economic activity of enterprises. The events of the previous and current years show that micro, small and medium-sized enterprises suffer the most from the consequences of the crisis, which, unlike large enterprises, do not have effective safeguards for timely detection and prevention of crisis threats. This requires businesses to identify in a timely manner, primarily operational risks, which include a decrease in business volumes and, as a consequence,
} 
a slowdown in the growth of operating income and a decrease in operating profit, which leads to an exacerbation of financial risks - reducing the profitability of operating activities, as well as the return on assets and capital of the enterprise and the deterioration of the financial condition of enterprises.

Factors of the crisis as a subject of crisis management are phenomena that are the causes of disruption of the stable development of the enterprise are described. Depending on the environment, the factors of the crisis are divided into external (which cannot be influenced by an individual enterprise) and internal (which are subject to regulation by the crisis management systems of the enterprise).

To identify the problematic parts of the trade enterprise, the modeling of operating profit is proposed, which is calculated by the method of direct calculation: increase in income and decrease in costs creates an increase in profit, decrease in income and increase in costs reduce profits by an appropriate amount. To reduce the risk and loss of solvency of the enterprise, the use of a payment calendar is recommended. Cash flows in the payment calendar are grouped by type of activity according to the areas of receipt and expenditure of funds, which allows to identify potential crisis threats in a timely manner and to form criteria for assessing the risk of insolvency. It is advisable to use the method of assessing potential bankruptcy according to a system of formalized and informal criteria, supplemented by an indicator of working capital, the negative value of which is a sign of the critical financial condition of the entity.

Effective crisis management of a trade enterprise is based on the use of information on indicators of operating and financial activities, the negative change of which leads to the formation of crisis situations. Given the limited resources of crisis management of a large number of enterprises operating in the commodity market of Ukraine, the article proposes a system of control and analytical procedures, the use of which allows to assess risks and identify safe economic activities without involving consulting audit firms and marketing agencies.

Key words: trade enterprise, crisis management, control and analytical procedures, operational and financial risks, minimization of crisis threats.

\section{JEL Classification: M13, M21, G32 \\ DOI: https://doi.org/10.36477/2522-1256-2021-29-05}

Постановка проблеми. Зростання кризових загроз, яке спостерігається останнім часом у світовому економічному середовищі, підвищує роль кризис-менеджменту в системі управління підприємствами, спрямовуючи керівництво на термінову оцінку операційних і фінансових ризиків та прийняття рішень щодо запобігання небажаним наслідкам впливу кризових чинників.

Методологія кризис-менеджменту визначає необхідність та місце застосування відповідних контрольно-аналітичних методичних прийомів (процедур). В умовах кризи пріоритетну роль відіграє внутрішній контроль, ефективність якого грунтується на залученні аналітичних процедур. Застосування останніх дає змогу визначити межи безпечної діяльності підприємства та прийняти обгрунтовані управлінські рішення. Проте низка показників, які визначають операційні та фінансові ризики, безпосередньо пов'язана з видом та обсягом діяльності підприємства, що унеможливлює їх застосування у кризис-менеджменті без відповідного коригування загальноприйнятих критеріїв оцінки. Так, коефіцієнти фінансової стійкості залежать від обсягу і характеру розміщення в активах власного капіталу. Оскільки розміщення власного капіталу починається 3 формування необоротних активів, то його надходження до обороту залежатиме від складності технології виробництва та від вартості устаткування, яке забезпечує дану технологію. На цьому етапі важливо взяти до уваги те, що критерій оцінки реальної вартості основних засобів (питома вага основних засобів у загальних активах підприємства) залежить не тільки від виду і обсягу діяльності та застосовуваної технології, а й від повноти використання виробничих потужностей підприємства: чим повніше реалізується потужність підприємства, тим нижчим за інших рівних умов має бути значення коефіцієнта реальної вартості основних засобів. Що стосується власного оборот- ного капіталу, то його обсяг залежить від швидкості обертання оборотних активів: потреба в оборотному капіталі буде тим меншою, чим швидше обертаються оборотні активи. Тобто підприємства з коротким технологічним циклом загалом потребують менше власного капіталу за рівних обсягів діяльності, ніж підприємства 3 тривалим циклом. Виходячи із цього, використання у кризис-менеджменті таких показників, як коефіцієнти автономії, мультиплікація капіталу, фінансовий леверидж, маневрування, реальна вартість основних засобів та ін., не може грунтуватися на середніх загальноприйнятих нормативних критеріях, які наводяться у спеціальній літературі. Винятком є показники платоспроможності, які характеризують покриття поточних зобов'язань різними видами оборотних активів, та коефіцієнти рентабельності, додатне значення яких свідчить про прибутковість діяльності (рентабельність доходів та/або витрат) та ефективність використання активів і власного капіталу (рентабельність загальних, або оборотних активів та рентабельність капіталу). Серед кризових чинників, що не потребують додаткового уточнення, треба назвати показники, розраховані на основі платіжного календаря, який розробляється на місяць із деталізацією відповідно до інформаційних потреб управління за днями, тижнями або декадами. Критеріями контролю у цьому разі є показники відхилення фактичних величин надходження і витрачання коштів від аналогічних показників платіжного календаря. За умови складання підприємцями звітів про рух грошових коштів для оцінки кризових ризиків можна запропонувати також коефіцієнти ефективності, ліквідності та достатності грошового потоку, які характеризують структуру грошового потоку і критерії оцінки яких також не потребують коригування.

Важливо зауважити, що необхідність уточнення й обгрунтування критеріїв оцінки кризових чинни- 
ків - не єдина проблема побудови системи відповідних показників кризис-менеджменту більшості підприємств торгівлі. Велика кількість різноманітних економічних показників, які значною мірою дублюють результати оцінки, на нашу думку, створює труднощі вибору й унеможливлює їх застосування для малих підприємств, серед яких переважають мікропідприємства, та значною мірою ускладнює застосування для середніх підприємств, більшість яких за чисельністю працюючих наближається до категорії малих підприємств. Разом із тим існуючи методики оцінки кризових ризиків орієнтовані на застосування у великих підприємствах. Саме великі підприємства мають службу внутрішнього аудиту, яка формує необхідну для кризис-менеджменту інформацію, і в разі потреби можуть звернутися до консалтингових аудиторських фірм та маркетингових агентств. Треба зауважити, що нині великі підприємства становлять менше одного відсотка у загальній кількості торговельних підприємств України [4; 5], отже, переважаюча чисельність суб'єктів підприємництва має певні труднощі у застосуванні сучасних методик оцінки кризових ризиків, причиною яких є обмеженість інформаційного, консультативного та програмного забезпечення, а також недостатній рівень кваліфікації кадрів.

Зважаючи на те, що розвиток малого підприємництва в Україні $є$ одним із пріоритетних напрямів регіональної політики, у статті запропоновано методику, що пропонує систему основних показників оцінки операційних і фінансових ризиків, яка не містить дублювання і може бути застосована у кризис-менеджменті будь-якого підприємства незалежно від фахового рівня його персоналу.

Аналіз останніх досліджень і публікацій. Загострення світової економічної кризи, спричинене пандемією, призвело до необхідності спрямування уваги на кризові загрози, які негативно впливають на результати діяльності підприємств торгівлі, серед яких переважають малі та середні підприємства. Разом із тим питання оцінки кризових чинників, від впливу яких потерпають суб'єкти підприємництва, розглядаються вітчизняними i закордонними вченими незалежно від розподілу підприємств на великі, середні та малі (серед яких переважають мікропідприємства). Більше того, складається враження, що наукові спрямування дослідників кризових загроз стосуються переважно великих підприємств, які мають усі можливості для застосування сучасних методів стратегічного управління, фінансового менеджменту (у тому числі кризисменеджменту), внутрішнього контролю (аудиту), економічного аналізу тощо. Теоретичні та методологічні аспекти антикризової стратегії знайшли відображення у фундаментальних працях вітчизняних і закордонних вчених [3-6; 9; 17; 18]. Більшість фахівців пов'язує кризові явища з інфляційними процесами як наслідком певних економічних змін зовнішнього середовища та внутрішніми чинниками, що зумовлюють фінансовий стан підприємства. Такий підхід призводить до того, що основна увага зосереджується на питаннях санації і банкрутства підприємства, а також питаннях управління фінансовими ризиками, зростання яких призводить до банкрутства $[1 ; 3-6 ; 9 ; 15 ; 18]$. Ризики операційної діяльності або взагалі не розглядаються, або розглядаються як складова частина фінан- сових ризиків: операційний ризик неотримання або неповного отримання очікуваного прибутку неправомірно відноситься до фінансових ризиків. Разом із тим початковою фазою розвитку кризи на підприємстві доцільно вважати кризу ефективності господарської діяльності, яка характеризується зростанням операційних ризиків [17]. Отже, загострення світової кризи внаслідок пандемії вимагає від суб'єктів підприємницької діяльності своєчасного виявлення, перш за все, операційних ризиків, до яких належать зменшення обсягів діяльності і, як наслідок, уповільнення зростання операційних доходів та зменшення операційного прибутку. Саме це, передусім, призводить до загострення фінансових ризиків: зниження рентабельності операційної діяльності, а також рентабельності активів та капіталу підприємства і погіршення фінансового стану підприємств.

Треба зауважити, що питання формування системи кризових чинників розглядаються у періодичних виданнях, присвячених як антикризовому управлінню [10-14], так i забезпеченню конкурентоспроможності підприємств в умовах ринкового середовища $[2 ; 16]$. Проте автори лишають поза увагою особливості впливу кризових загроз на малі та середі підприємства в умовах загострення кризових явищ.

Огляд публікацій дав змогу окреслити питання, що потребують подальшого розвитку в умовах загострення економічної кризи. У статті запропоновано систему контрольно-аналітичних процедур кризисменеджменту, орієнтованих на застосування малими i середніми підприємствами торгівлі.

Постановка завдання. Метою статті є розроблення й обгрунтування методичних засад застосування контрольно-аналітичних процедур у системі кризисменеджменту малих і середніх підприємств торгівлі в умовах загострення світової економічної кризи.

Виклад основного матеріалу дослідження. Формування ринку в економіці України грунтується на становленні та розвитку приватної власності і товарногрошових відносин. Спираючись на принципи свободи підприємництва, ринкові економічні відносини створюють необхідні умови для позитивних зрушень, які забезпечують розподіл ресурсів, виробництво, обмін і споживання товарів та послуг відповідно до попиту і пропозиції. Разом із тим притаманні ринку кризові загрози вимагають створення особливої ланки управління підприємством, завданнями якої $\epsilon$ виявлення, оцінка та запобігання негативному впливу кризових чинників на результати діяльності підприємства. Отже, ефективність діяльності підприємств торгівлі в умовах економічної кризи значною мірою залежить від якості управління кризовими чинниками, які зумовлюють рівень операційних і фінансових ризиків. Система кризис-менеджменту грунтується на застосуванні контрольно-аналітичних методів оцінки ризиків і визначенні шляхів запобігання кризовим загрозам відповідно до отриманих результатів.

Чинники кризи як предмет антикризового управління являють собою явища, що є причинами порушення стабільного розвитку підприємства. Залежно від середовища виникнення чинники кризи розподіляються на зовнішні (на зміну яких окреме підприємство впливати не може) та внутрішні (які піддаються регулюванню з боку систем антикризового управління 
підприємством). Загострення зовнішніх кризових загроз у 2019-2021 pр., яке є наслідком пандемії, актуалізувало необхідність дослідження внутрішніх чинників ризику з метою зниження їхнього негативного впливу на стан та розвиток підприємства. Внутрішні чинники розподіляються на суб'єктивні та об'єктивні. Суб'єктивні чинники є предметом внутрішнього контролю як наслідки помилок та зловживань у сфері господарської діяльності, безпосередньо не пов'язані 3 впливом кризових явищ. Отже, запропонована методика стосується об'єктивних кризових чинників, які потрапляють у сферу інтересів антикризового управління. Важливою особливістю антикризового управління $\epsilon$ застосування контрольно-аналітичних процедур у системі кризис-менеджменту підприємства, завданням яких $є$ своєчасне виявлення об'єктивних внутрішніх ризиків господарської діяльності. Оцінка об'єктивних внутрішніх ризиків передбачає їх розподіл на операційні та фінансові. Операційні ризики стосуються втрати частини прибутку внаслідок неотримання очікуваних доходів та перевищення очікуваних витрат. Фінансові ризики (кредитний, процентний, валютний, інвестиційний та ін.) пов'язуються з імовірною втратою фінансових ресурсів (грошових коштів) унаслідок змін на фінансовому ринку, що загрожують підприємству банкрутством.

Зважаючи на особливу вразливість малого і середнього бізнесу в умовах загострення світової економічної кризи, запропоновано таку послідовність етапів оцінки кризових ризиків та шляхів подолання негативних зрушень в економіці підприємства:

- визначення й оцінка елементів операційних ризиків на основі застосування адитивної моделі операційного прибутку;

- оцінка ризику втрати операційного прибутку за методом операційного важеля;

- оцінка ризику зниження або втрати платоспроможності підприємства на основі платіжного календаря;

- інтегральна оцінка ймовірного банкрутства підприємства за системою формалізованих критеріїв.

Адитивні моделі використовуються у тому разі, коли результативний показник (y) являє собою алгебраїчну суму декількох факторних показників $\left(x_{i}\right)$ :

$$
y=x_{1}+x_{2}+x_{3}+\ldots+x_{n}=\sum_{i=1}^{n} x_{i} .
$$

Операційний прибуток як фінансовий результат операційної діяльності підприємства знаходиться у функціональному зв'язку з операційними доходами і витратами, які по відношенню до прибутку є чинниками першого ряду. Для деталізації впливів на результативний показник доцільно розподілити факторні показники за їхнім складом. Так, операційні доходи підприємства торгівлі складаються з доходу (виручки) від реалізації продукції (товарів, робіт, послуг) та інших доходів, пов'язаних з операційною діяльністю. А операційні витрати включають собівартість реалізованої продукції (товарів, робіт, послуг), адміністративні витрати, витрати на збут та інші операційні витрати.

Для оцінки впливу кожного чинника на формування операційного прибутку (П) доцільно застосувати адитивну модель, яка має вигляд:

$$
\Pi=\Sigma Д_{j}-\Sigma B_{k}
$$

де $Д_{j}-$ вид операційного доходу;
$B_{j}$ - вид операційних витрат, здійснення яких спрямоване на отримання операційного доходу.

Залежно від того, які види доходів та витрат включено до наведеного вище алгоритму, здійснюється моделювання утворення операційного, прибутку. Вплив чинників на зміну операційного прибутку за даною моделлю розраховується методом прямого рахунку: збільшення доходів та зменшення витрат створюють приріст прибутку i, навпаки, зниження доходів та зростання витрат зменшують прибуток на відповідну величину. Деталізація чинників дає змогу визначити проблемні ланки і вжити заходи щодо усунення недоліків.

Метод операційного важеля грунтується на принципі розподілу витрат підприємства торгівлі за ознакою залежності від обсягу реалізації товарів (робіт, послуг). Згідно із цим принципом, витрати поділяють на змінні та постійні. Змінні (виробничі) витрати (v) знаходяться у прямій пропорційній залежності від обсягу реалізації. Постійні (періодичні) витрати (c) не залежать від обсягу реалізації, їхня величина відповідає тривалості періоду дослідження. Запропонована модель операційного важеля характеризує зв'язок між співвідношенням постійних і змінних витрат та операційним прибутком (p). Операційний прибуток являє собою різницю між доходом від реалізації товарів, робіт, послуг $(R)$ та постійними $(c)$ і змінними $(v)$ витратами підприємства: $p=R-c-v$. Застосування методики операційного важеля дає змогу пов'язати втрату операційного прибутку зі зменшенням чистого доходу від реалізації продукції. У табл. 1 наведено етапи оцінки ризику втрати операційного прибутку на основі застосування методики операційного важеля.

В оперативному управлінні ризиком зниження або втрати платоспроможності підприємства здійснюється на основі платіжного календаря. Платіжний календар являє собою оперативний фінансовий план надходжень і витрачань грошових коштів на поточний місяць із деталізацією відповідно до інформаційних потреб управління за днями, тижнями або декадами. Грошові потоки підприємства торгівлі у платіжному календарі групуються за видами діяльності відповідно до напрямів надходження і витрачання коштів, що дає змогу своєчасно встановити потенційні кризові загрози. Структуру платіжного календаря підприємства торгівлі наведено в табл. 2.

Чистий рух коштів визначається як різниця між показниками надходжень і витрачань коштів, відкоригована на величину залишків коштів на початок i кінець періоду.

Контроль ризиків зниження або втрати платоспроможності здійснюється за показниками відхилення фактичних величин надходжень i витрачань коштів від аналогічних показників платіжного календаря. Критерії оцінки ризику неплатоспроможності на основі виконання платіжного календаря наведено в табл. 3.

Методика оцінки потенційного банкрутства за системою формалізованих і неформалізованих критеріїв грунтується на визначенні різноманітних фінансових показників та співвідношень і порівнянні їх із рекомендованими критеріями [15]. Зважаючи на особливості формування активів підприємств торгівлі, які проявля- 
Оцінка ризику втрати прибутку за методом операційного важеля

\begin{tabular}{|l|c|}
\hline \multicolumn{1}{|c|}{ Характеристика етапу розрахунку показників } & Алгоритм розрахунку \\
\hline Розподіл операційних витрат на постійні (с) і змінні (v) & $p=R-c-v$ \\
\hline Визначення величини операційного прибутку (р) & $D O L=\frac{R-v}{p}$ \\
\hline Розрахунок ступеню операційного важеля $(D O L)$ & $-\Delta p_{\%}=D O L \cdot\left(-\Delta R_{\%}\right)$ \\
\hline $\begin{array}{l}\text { Оцінка ризику втрати частки операційного прибутку }\left(-\Delta p_{\%}\right) \text { внаслідок } \\
\text { зменшення доходу від реалізації на } 1 \%\left(\Delta R_{\%}=1 \%\right)\end{array}$ \\
\hline $\begin{array}{l}\text { Критерії оцінки ризику зниження операційного прибутку внаслідок } \\
\text { зменшення доходу від реалізації товарів за показником «- }-\Delta p_{\%} » \\
\text { (джерело: уточнено автором): } \\
\text { Високий ризик } \\
\text { Звичайний ризик } \\
\text { Низький ризик }\end{array}$ \\
\hline
\end{tabular}

Джерело: розроблено автором

Таблиця 2

Приблизний зміст платіжного календаря підприємства торгівлі

\begin{tabular}{|c|c|}
\hline Надходження коштів & Витрачання коштів \\
\hline \multicolumn{2}{|c|}{ Операційна діяльність } \\
\hline $\begin{array}{l}\text { Реалізація товарів } \\
\text { Погашення дебіторської заборгованості } \\
\text { Повернення з бюджету ПДВ } \\
\text { Інші операційні надходження }\end{array}$ & \begin{tabular}{|l} 
Оплата товарів \\
Оплата праці \\
Оплата зобов'язань з ПдВ \\
Оплата зобов'язань з податку на прибуток \\
Відрахування на соціальні заходи \\
Інші витрачання \\
\end{tabular} \\
\hline \multicolumn{2}{|c|}{ Чистий рух коштів від операційної діяльності } \\
\hline \multicolumn{2}{|c|}{ Інвестиційна діяльність } \\
\hline $\begin{array}{l}\text { Реалізації необоротних активів } \\
\text { Реалізація фінансових інвестицій } \\
\text { Отримані відсотки і дивіденди } \\
\text { Інші надходження }\end{array}$ & $\begin{array}{l}\text { Розвиток підприємства } \\
\text { Інші витрачання }\end{array}$ \\
\hline \multicolumn{2}{|c|}{ Чистий рух коштів від інвестииійної діяльності } \\
\hline \multicolumn{2}{|c|}{ Фінансова діяльність } \\
\hline $\begin{array}{l}\text { Отримані позики } \\
\text { Інші надходження }\end{array}$ & $\begin{array}{l}\text { Погашення позик } \\
\text { Інші витрачання }\end{array}$ \\
\hline \multicolumn{2}{|c|}{ Чистий рух коштів від фінансової діяльності } \\
\hline \multicolumn{2}{|c|}{ Узагальнення показників платіжного календаря } \\
\hline $\begin{array}{l}\text { Залишок коштів на початок періоду } \\
\text { Надходження коштів }\end{array}$ & $\begin{array}{l}\text { Витрачання коштів } \\
\text { Залишок коштів на кінець періоду }\end{array}$ \\
\hline \multicolumn{2}{|c|}{ Чистий рух коштів } \\
\hline
\end{tabular}

Джерело: розроблено автором

Критерії оцінки ризику зниження або втрати платоспроможності підприсмства торгівлі на основі платіжного календаря

\begin{tabular}{|l|l|}
\hline \multicolumn{1}{|c|}{$\begin{array}{c}\text { Критерії оцінки ризику зниження } \\
\text { платоспроможності }\end{array}$} & \multicolumn{1}{c|}{ Характеристика грошового потоку } \\
\hline Дуже високий ризик & Сукупні надходження < Сукупні витрачання \\
\hline \multirow{2}{*}{ Високий ризик } & Операційні надходження $\leq$ Операційні витрачання \\
\cline { 2 - 2 } & Чистий рух коштів від операційної діяльності $\leq$ Термінові виплати ${ }^{1}$ \\
\hline Звичайний ризик & Операційні надходження > Операційні витрачання \\
\hline \multirow{2}{*}{ Низький ризик } & Сукупні надходження > Сукупні витрачання \\
\cline { 2 - 2 } & Чистий рух коштів від операційної діяльності $\geq$ Термінові виплати1 \\
\cline { 2 - 2 } & Чистий рух коштів $>0$ \\
\hline${ }^{1}$ Термінові виплати: погашення позик, виплата дивідендів та здійснення інших поточних платежів \\
\hline
\end{tabular}

Джерело: розроблено автором 
Таблиця 4

Критерії інтегральної оцінки ймовірного банкрутства за системою формалізованих критеріїв

\begin{tabular}{|c|c|c|}
\hline Критерій оцінки ймовірного банкрутства & Оцінка фінансової стійкості & Умовні позначення \\
\hline $3 B<B O K$ & Абсолютна фінансова стійкість & \multirow{5}{*}{$\begin{array}{c}\text { ЗВ - залишки запасів і витрат } \\
\text { ВОК - залишки власного оборотного } \\
\text { капіталу } \\
\text { ДФ } 3_{\text {ноРм }} \text { - нормальні джерела } \\
\text { формування запасів і витрат (власний } \\
\text { оборотний капітал, короткострокові } \\
\text { кредити банків, кредиторська } \\
\text { заборгованість за товари, векселі } \\
\text { видані, поточні зобов’язання } \\
\text { з одержаних авансів) }\end{array}$} \\
\hline ВОК $<3$ ЗВ $<$ ДФЗНОРМ & Нормальна фінансова стійкість & \\
\hline $3 B>Д \Phi 3_{H O P M}$ & Нестійкий фінансовий стан & \\
\hline $\begin{array}{c}3 B>Д \Phi 3_{H о р м} \\
\text { (за умови, що підприємство має прострочені } \\
\text { кредити, кредиторську і дебіторську } \\
\text { заборгованість) }\end{array}$ & Критичний фінансовий стан & \\
\hline ВОК < 0 (джерело: запропоновано автором) & Загроза банкрутства & \\
\hline
\end{tabular}

Джерело: розроблено автором

ються у фінансуванні необоротних активів за рахунок частки поточних зобов'язань [7; 8], нами запропоновано додати до характеристик ймовірного банкрутства показник власного оборотного капіталу, від'ємне значення якого є ознакою критичного фінансового стану. Отже, запропоновані зміни надали методиці оцінки ймовірного банкрутства такого вигляду (табл. 4).

Підсумовуючи наведене вище, можна стверджувати, що ефективне антикризове управління підприємством торгівлі грунтується на використанні інформації стосовно показників операційної і фінансової діяльності, негативна зміна яких призводить до утворення кризових ситуацій. Отже, основними завданнями кризис-менеджменту малих і середніх підприємств торгівлі є локалізація кризових чинників, що стали причинами утворення ризикових ситуацій, за місцями та причинами їх виникнення.

Висновки 3 проведеного дослідження. У статті розглянуто контрольно-аналітичні процедури, спрямовані на визначення й оцінку ризиків утрати операційного прибутку, погіршення платоспроможності та ймовірного банкрутства підприємства торгівлі.

Запропоновано моделювання операційного прибутку, що розраховується методом прямого рахунку: збільшення доходів та зменшення витрат створюють приріст прибутку, а зниження доходів та зростання витрат зменшують прибуток на відповідну величину 3 метою визначення проблемних ланок діяльності підприємства торгівлі. Рекомендовано використання платіжного календаря для зниження ризику та втрати платоспроможності підприємства. Грошові потоки у платіжному календарі групуються за видами діяльності відповідно до напрямів надходження і витрачання коштів, що дає змогу своєчасно встановити потенційні кризові загрози та сформувати критерії оцінки ризику неплатоспроможності. Доцільне використання методики оцінки потенційного банкрутства за системою формалізованих i неформалізованих критеріїв, що доповнена показником власного оборотного капіталу, від'ємне значення якого $є$ ознакою критичного фінансового стану суб'єкта господарювання.

Застосування розглянутих вище показників та критеріїв оцінки операційних і фінансових ризиків у системі кризис-менеджменту малих і середніх підприємств торгівлі є передумовою своєчасного виявлення та недопущення подальшого розвитку кризових явищ в умовах загострення світової економічної кризи.

\section{ЛІТЕРАТУРА}

1. Андрушко О. В. Економічне діагностування кризового стану та загрози банкрутства машинобудівного підприємства : автореф. дис. ... канд. екон. наук : 08.04.01. Львів, 2007. 23 с.

2. Барабаш Н., Ріпа Т. Аудиторська оцінка конкурентоспроможності підприємств торгівлі. Зовнішня торгівля: економіка, фінанси, право. 2018. № 1. С. 111-120.

3. Бланк И. А. Антикризисное финансовое управление предприятием. Киев : Ника-Центр, 2006. 672 с.

4. Бригхем Ю. Основы финансового менеджмента. Москва : Молодежь, 2012. 323 с.

5. Василенко В. О. Антикризове управління підприємством : навчальний посібник ; 2-е вид., випр. і доп. Київ : Центр навч. л-ри, 2005. 501 с.

6. Глущенко В. В. Введение в кризисологию. Финансовая кризисология. Антикризисное управление . Москва : Глущенко В. В., 2008. 88 с.

7. Держстат України, 1998-2020. Дата останньої модифікації: 31.12.2020. URL: www.ukrstat.gov.ua (дата звернення: 05.02.2021).

8. Діяльність суб'єктів великого, середнього, малого та мікропідприємництва : статистичний збірник / Державна служба статистики України. Київ, 2019. 153 с.

9. Ковалев В. В. Финансовый менеджмент: теория и практика ; 3-е изд., перераб. и доп. Москва : Проспект, 2014.

10. Коваленко О. В. Антикризове управління - запорука стабільності роботи підприємства. Вісник Хмельницького національного університету. 2011. № 2. Т. 3. C. $65-68$.

11. Коцеруба Н. В. Оцінка операційних і фінансових ризиків у системі антикризового управління підприємством роздрібної торгівлі. Актуальні проблеми економіки. 2010. № 2(104). C. 120-128.

12. Коцеруба Н. В. Критерії оцінки кризових ризиків в аудиті фінансового стану підприємств роздрібної торгівлі. Бухгалтерський облік, аналіз та аудит: проблеми теорії, методології, організації. Спеціальний випуск. 2010. № 4. C. 89-96.

13. Коцеруба Н. В. Система критеріїв оцінки кризових явищ на підприємствах роздрібної торгівлі. Облік як інформаційна система для економічної безпеки підприємств в конкурентному середовищі : матеріали міжнародної науково-практичної конференції, м. Тернопіль, 25-26 листопада 2010 р. Тернопіль, 2010. С. 215-218.

14. Маховка В. М. Методологія формування системи антикризового управління підприємством. Інноваційна економіка. 2013. № 1(39). С. 102-105.

15. Аналіз і контроль в системі управління капіталом підприємства / Є.В. Мних та ін. ; за ред. Є. В. Мниха. Київ : КНТЕУ, 2005. 232 с. 
16. Ріпа Т. В. Сутність та класифікація факторів конкурентоспроможності підприємств торгівлі. Конкурентоспроможність національної економіки: показники, фактори впливу та шляхи підвищення : матеріали Всеукраїнської науково-практичної конференції, м. Київ, 30 вересня 2016 р. : у 2-х ч. Київ : Київський економічний науковий центр, 2016. Ч. 2. С. 94-96.

17. Скібіцький М. О. Антикризовий менеджмент : навчальний посібник. Київ : Центр учбової літератури, 2009. $568 \mathrm{c}$.

18. Ткаченко А. М. Концептуальні підходи до антикризового управління в сучасних умовах господарювання : монографія. Запоріжжя : ЗДІА, 2010. 356 с.

\section{REFERENCES}

1. Andrushko, O. V. (2007), Economic diagnosis of the crisis and the threat of bankruptcy of the machine-building enterprise: dissertation abstract for the degree of candidate's thesis, Lviv, Extended abstract of candidate's thesis, Ukraine.

2. Barabash, N. and Ripa, T. (2018), Audytorska otsinka konkurentospromozhnosti pidpryiemstv torhivli. Zovnishnia torhivlia: ekonomika, finansy, pravo, KNTEU, Kyiv, Ukraine.

3. Blank, Y. A. (2006), Anti-crisis financial management of the enterprise, Nyka-Tsentr, Kyiv, Ukraine.

4. Bryhkhem, Yu. (2012), Fundamentals of financial management, Molodezh, Moskva, Russia.

5. Vasylenko, V. O. (2005), Anti-crisis management of the enterprise (2rd ed., rev.), Tsentr navch. 1-ry, Kyiv, Ukraine.

6. Hlushchenko, V. V. (2008), Introduction to crisisology. Financial crisisology. Crisis management, YP Hlushchenko V. V., Moskva, Russia.

7. State Statistics Service of Ukraine, 1998-2020. Data ostannoi modyfikatsii: 31.12.2020, available at: www.ukrstat.gov.ua

8. Activities of large, medium, small and micro enterprises. Statistical collection. (2019), Derzhavna sluzhba statystyky Ukrainy, Kyiv, Ukraine.
9. Kovalev, V. V. (2014), Financial management: theory and practice, № 3, available at: http://ijevanlib.ysu.am/wpcontent/uploads/2018/01

10. Kovalenko, O. V. (2011), "Anti-crisis management is the key to the stability of the enterprise", Visnyk Khmelnytskoho natsionalnoho universytetu, № 2 (3), s. 65-68.

11.Kotseruba, N. V. (2010), "Assessment of operational and financial risks in the system of crisis management of the retail enterprise", Aktualni problemy ekonomiky, № 2, s. 120-128.

12. Kotseruba, N. V. (2010), "Criteria for assessing crisis risks in the audit of the financial condition of retail enterprises", Bukhhalterskyi oblik, analiz ta audyt: problemy teorii, metodolohii, orhanizatsii, № 4, s. 89-96.

13. Kotseruba, N. V. (2010), System of criteria for assessing crisis phenomena at retail enterprises. Oblik yak informatsiina systema dlia ekonomichnoi bezpeky pidpryiemstv $v$ konkurentnomu seredovyshchi: materialy mizhnarodnoi naukovo - praktychnoi konferentsii, Ternopil, Ukraine.

14. Makhovka, V. M. (2013), "Methodological formation of the crisis management system of the enterprise", Innovatsiina ekonomika, № 1 (39), s. 102-105.

15. Mnykh, Ye. V., Butko, A. D., Bolshakova, O. Iu., Kravchenko, H. O., Nykonovych, H. I. (2005), Analysis and control in the capital management system of the enterprise, KNTEU, Kyiv, Ukraine.

16. Ripa, T. V. (2016), Competitiveness of the national economy: indicators, factors of influence and ways to increase: materialy Vseukrainskoi naukovo-praktychnoi konferentsii (pp. 94-96). Kyiv: HO «Kyivskyi ekonomichnyi naukovyi tsentr» [in Ukrainian].

17. Skibitskyi, M. O. (2009), Crisis management. Navch. posibnyk, Tsentr uchbovoi literatury, Kyiv, Ukraine.

18. Tkachenko, A. M. (2010), Conceptual approaches to crisis management in modern business conditions, Vyd-vo Zaporizkoi Derzhavnoi inzhenernoi akademii, Zaporizhzhia, Ukraine.

Стаття надійшла до редакиії 15 березня 2021 р. 